\title{
FINANCIAL ASSISTANCE FOR THE SUBSCRIPTION OF SECURITIES: A COMPARISON OF SECTION 38 OF THE COMPANIES ACT 61 OF 1973 AND SECTION 4 OF THE COMPANIES ACT 71 OF 2008*
}

\author{
Tshegofatso Kgarabjang \\ LLB LLM LLM \\ Lecturer, Department of Mercantile Law \\ University of South Africa (UNISA)
}

\section{SUMMARY}

Section 38 of the Companies Act 61 of 1973 prohibited a company to provide financial assistance for the acquisition of shares not only in the company itself or its holding company but also subsidiary. The legislature, when amending section 38, through the Companies Amendment Act 37 of 1999 failed to remove the prohibition in section 38, only incorporating solvency and liquidity test. Section 44 of the new Companies Act 71 of 2008 permits a company to provide financial assistance for the acquisition of or subscription of company's securities, not only in the holding company but also in the subsidiary (or related company). The aim of this article is to compare section 38 of the old Act and section 44 of the new Act and highlight changes made by the section 44 .

\section{HISTORICAL BACKGROUND}

A company requires capital from investors in order to exist, continue its existence and carry out its function. Capital rules were developed to protect creditors and both present and future directors. South Africa was one of the few countries that applied the principle of capital maintenance. ${ }^{1}$ According to the doctrine of capital maintenance, a company is prohibited from giving financial assistance for the acquisition of shares in the company itself or in its holding company. During the last two decades of the nineteenth century, the English courts established the main principle that shares may not be

This article stems from the author's LLM dissertation entitled A Critical Analysis of Sections 44, 45 and 48 of the Companies Act 71 of 2008 (University of Pretoria 2012).

1 Cilliers, Benade, Henning, Du Plessis, Delport, De Koker, Pretorius Cilliers and Benade Corporate Law 3ed (2000) 322. 
issued at a discount to their par value ${ }^{2}$ a company may not purchase its own shares ${ }^{3}$ and dividends may not be paid out of share capital. ${ }^{4}$ The doctrine of capital maintenance was accepted as part of South African Company Law and later entrenched in the Companies Act 61 of 1973.

The doctrine of capital maintenance was criticized by several authors. ${ }^{5}$ Some authors expressed their view that capital maintenance rules are not unnecessarily complex and riddled with obscurities, but worse still many of these rules have outlived their usefulness. ${ }^{6}$

The decision in Trevor $v$ Whitworth which prohibits a company to purchase its own shares remained part of South African law until 30 June 1999, when the Companies Act of 1973 was amended by the Companies Amendment Act 37 of 1999. Section 38 of the old Act which prohibits a company from giving a financial assistance for the acquisition of shares in the company itself or in its holding company, ${ }^{7}$ was amended by section 90 of the Companies Amendment Act of 1999. The common-law rule that dividends may not be paid out of capital ${ }^{8}$ was supplemented by the rule that dividends could be paid out of profits only. ${ }^{9}$ The Companies Amendment Act also permits companies not only to return share capital to their shareholders by buying shares back from them, but also to pay dividends out of shares capital. ${ }^{10}$ The legislature, when eliminating the prohibition in section 38 , failed to remove the prohibition. The solvency and liquidity test has been incorporated as a substitute for the capital-maintenance principle since positive results in terms of the aforesaid tests are considered as adequate protection for the minority. The new Act allows a company to provide

2 Ooregum Gold Mining Company of India v Roper (1892) AC 125. In Ooregum the issue of shares at a discount was completely bona fide and saved the company. The House of Lords indicated that the allottees had to be liable to pay for the shares in full. Lord Halsbury said the nominal capital of the company was "fixed and certain, and every creditor of the company is entitled to look to that capital as his security". See also Knight "Capital Maintenance" 19951 Perspective on Company Law 54.

3 Trevor $v$ Whitworth (1887) 12 App Cas 409 (HL).

4 Guinness $v$ Land Corporation of Ireland (1882) 22 Ch D 349 356. The per Cotton LJ indicated that "[W]hatever has been paid by a member cannot be returned to him. ... [W]hat is described in the memorandum as the capital cannot be diverted from the objects of the society. It is, of course, liable to be spent or lost in carrying on the business of the company, but no part of it can be returned to a member so as to take away from the fund to which the creditors have a right to look as that out of which they are to be paid" 375 .

5 See McGee Share Capital (1999) 2 and 3; Farrar, Furey, Hannigan and Wylie Farrar's Company Law (1998) 184-185; Van der Linde "Aspects of the Regulation of Share Capital and Distributions to Shareholders" (LLD thesis, University of South Africa 2008) 20 and 21; Cassim "The Reform of Company Law and the Capital Maintenance Concept" 2005 SALJ 283 284; and Knight 19951 Perspective on Company Law 52.

6 Cassim 2005 SALJ 284.

7 Companies Act 61 of 1973. See Cilliers et al Cilliers and Benade Corporate Law 329; Benade, Henning, Du Plessis, Delport, De Koker and Pretorius Entrepreneurial Law (2008) 192; and see also Blackman, Jooste and Everingham Commentary on the Companies Act (2002) 4-55.

$8 \quad$ Guinness v Land Corporation of Ireland supra 356; and Re Exchange Banking Co, Flitcroft's Case (1882) 21 ChD 591.

9 See Davies Gower \& Davies' Principles of Modern Company Law 7ed (2003) 275; and Van der Linde (LLD thesis, University of South Africa 2008) 23.

10 Van der Linde "Capital Maintenance is Dead-long Live Solvency and Liquidity" 19997 JBL 155. 
financial assistance, provided that the provisions of section 44(3) and 44(4) are complied with. ${ }^{11}$ In particular, the new Act is based on solvency and liquidity tests and any remnant of the capital maintenance on which the 1973 Act was based is now removed. ${ }^{12}$

The purpose of this article is to investigate the changes made by section 44 of the Companies Act 71 of 2008. In order to achieve this aim, a critical analysis of section 38 of the old Act and section 44 of the new Act will be done.

\section{SECTION 38 OF THE COMPANIES ACT 61 OF 1973}

As indicated above, a company is prohibited, whether directly or indirectly, from giving financial assistance for the acquisition of shares in the company itself or in its holding company. ${ }^{13}$ Therefore where a company concerned is a subsidiary the prohibition also extends for financial assistance in respect of the purchase or subscription of shares in its holding company. ${ }^{14}$ Section 54 of the English Companies Act, 1948 is identical to section 38(1). The court, in Lipschitz $v$ UDC Bank, ${ }^{15}$ indicated that the prohibition in section 38 comprises two main elements, namely, the giving of financial assistance and the purpose for which it is given (or the "in connection with" provision). ${ }^{16}$

11 S 44(3) provides that despite any provision contrary to the MOI, the Board may not authorize any financial assistance unless it is pursuant to an employee-share scheme that satisfies the requirements of section 97 or pursuant to a special resolution of the shareholders, adopted within the previous 2 years, which approved such assistance. This section further states that the Board must be satisfied that immediately after providing the financial assistance, the company will satisfy the solvency and liquidity test and the terms under which the financial assistance is proposed are fair and reasonable to the company. $S$ 44(4) imposes duty on the board to ensure that any conditions or restrictions respecting the granting of financial assistance set out in the company's MOI have been satisfied.

12 Delport The New Companies Act Manual (2011) 53.

13 S 38(1) of the Companies Act 61 of 1973. See Cilliers et al Cilliers and Benade Corporate Law 329; Benade et al Entrepreneurial Law 192; see also Blackman et al Commentary on the Companies Act 4-55; and Oelofse "Artikel 38 van die Maatskappywet" 1980 TSAR 47 on the scope and application of $\mathrm{s} 38$.

14 Armour v Hick Northern Ltd v Armour Trust Ltd [1980] 3 All ER 833 (Ch); Belmont Finance Corporation v Williams Furniture [1980] 1 All ER 393 (CA).

151979 (1) SA 789 (A) 799. See De Bruin "Artikel 38(1) van die Maatskappywet" 1979 De Rebus 361; see also Lewis v Oneanate (Pty) Ltd 1992 (4) SA 811 (A); Cilliers et al Cilliers and Benade Corporate Law 331; and Pretorius, Delport, Havenga and Vermaas Hahlo's South African Company Law Through the Cases 6ed (1999) 131.

16 In Lewis $v$ Oneanate (Pty) Ltd supra 816-817 the court indicated that the following propositions could be extracted from Lipschitz with regard to financial assistance:

1. The prohibition against the giving of financial assistance is couched in very wide terms. It relates to "any" financial assistance, whether given "directly or indirectly" and it relates to such assistance not only when it is given for the purpose of the purchase of or subscription for any shares in the company, but also when it is given "in connection with" such purchase or subscription (797D-E).

2. The prohibition contains two main elements - the giving of financial assistance, and the purpose for which it is given. Although the two elements are linked to form a single prohibition, they are vitally different in concept (799E).

3. There is no comprehensive definition of "financial assistance" in the section or elsewhere in the Act. From time to time various tests have been formulated by the courts as a guide to a proper answer to the question whether what a company has done 
It is submitted that the purpose of section 38 is to ensure that corporate funds are used for proper corporate purposes. ${ }^{17}$ Cassim submits that section 38 simply ensures that persons who purchase shares in a company do so out of their own funds and not by the plundering the resources of the company to the prejudice of creditors and minority shareholders. ${ }^{18}$

\section{SECTION 38 AND SUBSIDIARY}

Section 38 does not permit a subsidiary to provide financial assistance to any person for the purchase or subscription of shares in its holding company. ${ }^{19}$ In other words, where a company concerned is a subsidiary, the prohibition for giving financial assistance in section 38 also extends to financial assistance in respect of purchase or subscription of shares in its holding company. ${ }^{20}$ It is submitted that the extension of section $38(1)$ to include a subsidiary ignores, for policy reasons, the fundamental principles of company law; namely the concept of legal personality established by the court in Salomon $v$ Salomon \& Co $L t d{ }^{21}$ where the court held that a subsidiary, like any other company, is to be regarded as a separate and distinct entity from its holding company. ${ }^{22}$ However, Cassim expresses that section 38(1) does not forbid provision of financial assistance for the

in a given case constitutes the giving of "financial assistance" within the meaning of the section (789C-E).

4. One such test is the so-called "impoverishment test", which asks the question, has the company become poorer as a result of what it did for the purpose of or in connection with purchase of its shares? (798C-E).

5. The application for the impoverishment test is not always appropriate. In some cases the test may be a helpful guide and may often yield a clear and decisive answer to the problem. In other cases it may not only unhelpful but irrelevant (801D-E).

6. The section provides in terms that the giving of a guarantee or the provision of security constitutes the giving of financial assistance. In such cases, if the giving of the guarantee or the providing of the security is shown to be for the purpose of or in connection with the purchase of the company's shares, the section would be contravened, whether or not such guarantee or security actually renders or is likely to render the company poorer (800-801).

7. Although the section does not in terms prohibit the conclusion of a contract for the sale of shares in which there is a provision for the giving of financial assistance, if a contact provides for the future financial assistance which if actually given would be in contravention of the section, it is invalid and unenforceable (802B-803C).

17 Blackman et al Commentary on the Companies Act 4-57; and Cassim 2005 SALJ 292.

18 Cassim 2005 SALJ 292.

19 Cassim "Unravelling the Obscurities of Section 38(2)(d) of the Companies Act" 2005 SALJ 494.

20 Cilliers et al Cilliers and Benade Corporate Law 329; Armour v Hick Northern Ltd v Armour Trust Ltd supra; Belmont Finance Corporation v Williams Furniture supra; and see Cassim 2005 SALJ 493.

21 [1897] AC 22(HL)

22 Cassim 2005 SALJ 493. See Adams v Cape Industries Plc [1991] ALL ER 927 (ChD and CA) 1019; and Acatos and Hutcheson Plc v Watson [1995] 1 BCLC 218 (ChD) 223e-f, where Slade LJ indicated that "our law for better or worse, recognizes the creation of subsidiary companies, which though in one sense the creatures of their parent companies, will nevertheless fail to be treated as separate legal entities with all the rights and liabilities which would normally attach to separate legal entities". 
purchase or subscription for shares in a subsidiary of the company, ${ }^{23}$ and he is of the opinion that there is less likelihood of prejudice to other shareholders and creditors. ${ }^{24}$ Gower indicates that sections $151-153$ of the Companies Act of $1985,{ }^{25}$ which prohibit the giving of financial assistance by a company for the purchase of shares, do not apply where financial assistance is given by the holding company for the acquisition of shares in its subsidiary company. ${ }^{26}$

Section $38(2)$ (d) provides that the provision of financial assistance in section 38(1) shall not be construed as prohibiting the acquisition of shares in a company by the company or its subsidiary in accordance with the provisions of section 85 for the acquisition of such shares. There are various interpretations regarding section 38(2)(b). Blackman et al indicate that the meaning of section $38(2)$ (d) is not obvious and "it is unclear how a company can give itself financial assistance to purchase its own shares or the shares of its holding company". ${ }^{27}$ They further indicate that "[p]erhaps it was intended that section $38(2)(d)$ should refer, not to section 85 but section $89 "{ }^{28}$ Cilliers et al also describe the provisions of section $38(2)(d)$ as a curious exception because it is the company that acquires shares and it is therefore impossible for the company to provide itself with financial assistance. ${ }^{29}$ Delport states that "what bedevilled the exclusions in section $38(2)$ (b) was that the reference was not to $s 85(4)$, which contains the solvency and liquidity requirements, but to the whole of $s 85$, which provides for the power of the company to acquire its own shares". ${ }^{30}$ Delport indicates that there are two possible interpretations; one being that the financial assistance is given by the company to its subsidiary for the acquisition of shares in the company by the subsidiary. ${ }^{31}$ In light of this interpretation, he submits that it seems to be logical as the subsidiary may now hold shares in the holding company (section 39 and 89 ). ${ }^{32}$ He indicates that, the second interpretation appears to be more problematic, because it may be that the exclusion covers instances where the financial assistance is provided by the subsidiary for the acquisition of shares of the holding company by the holding company in terms of section $85 .^{33}$ He concludes that, due to these uncertainties, the exclusion contained in section $38(2)(b)$ is therefore virtually useless. ${ }^{34}$ The view expressed by Delport is rejected by Van der Linde. ${ }^{35}$ In particular, Van der Linde disagrees with the view that the exclusion allows or

23 Cassim 2005 SALJ 494; and Parker and Buckley Buckley on the Companies Act 14ed (1981) 156 in relation to s 54 English Companies Act, 1948 which is identical to s 38.

24 Cassim 2005 SALJ 494.

25 English legislation.

26 Davies Gower and Davies Principle of Modern Company Law 261 (fn 52).

Blackman et al Commentary on the Companies Act 4-66.

28 Ibid.

29 Cilliers et al Cilliers and Benade Corporate Law 330 (fn 52).

30 Delport "Company Groups and the Acquisition of Shares" 200113 SA Merc LJ 121 125126.

31 Ibid.

32 lbid.

33 Ibid.

34 Ibid.

35 Van der Linde "Financial Assistance for the Acquisition of Shares in Accordance with S 85 of the Companies Act - A Reply to Delport” 2001 SA Merc LJ 437438. 
purports to allow the giving of financial assistance by the company itself. She believes that section 38(2)(b) has the following effect:

- "A subsidiary may give financial assistance (to its holding company or any other person) in connection with the acquisition by the holding company of its (the holding company's) own shares.

- A holding company may render assistance to its subsidiary company or to any other person) in connection with the acquisition by the subsidiary of shares in the holding company.

- A co-subsidiary of a subsidiary acquiring shares in its holding company may give assistance (to the subsidiary or any other person) in connection with the acquisition by the subsidiary of shares in the holding company"."

Cassim is of the opinion that in order to explain the meaning and effect of section 38(2)(b), it will be useful to go back to its origin in 1999 as well as the origins of section $38(1){ }^{37} \mathrm{He}$ disagrees with Blackman et al and Delport when they expressed the view with reference to section 38(2)(b) that the person who acquires the shares is the company, so the exclusion applies to financial assistance given to the company by the company. ${ }^{38}$ Cassim concludes by stating that the consequence of section $38(2)(d)$ is that the financial assistance which may only be given to its subsidiary or fellow subsidiary will be subject to approval by special resolution, authorization in the articles of association of the company and compliance with the test of "liquidity and solvency". ${ }^{39}$ He further states that "the net result of second part of section 38(2)(b) is that it facilitates, subject to vital safeguard, the injection of capital into a subsidiary by its holding company to enable the subsidiary to acquire the shares of its holding company without any fear that this would constitute indirect financial assistance contrary to section $38(2)(d)$ ".

\section{THE COMPANIES AMENDMENT ACT 37 OF 1999}

Section 38 was amended by section 3 of the Companies Amendment Act of 1999 by insertion of section (2)(d) in order to provide for further exemption to the prohibition. In particular, when amending section 38, the legislature failed to remove the prohibition. Only the solvency and liquidity test was incorporated into share repurchase provision as a substitute for the capital maintenance and is considered to be an adequate safeguard for minority shareholders and creditors. ${ }^{41}$ Section $4(1)$ stipulates that the company satisfies a solvency and liquidity test at a particular time if considering all reasonably foreseeable financial circumstances of the company at that time, the assets of the company as fairly valued equal or exceeding the liability of the company, and it appears that the company will be able to pay its debts as they become due in the ordinary course of business for the period of 12 months from the date on which the test is considered.

\footnotetext{
Van der Linde 2001 SA Merc LJ 442.

Cassim 2005 SALJ 495 and 496.

38 See Delport 200113 SA Merc LJ 125-126; and Blackman et al Commentary on the Companies Act 4-66.

9 Cassim 2005 SALJ 500.

40 lbid.

41 Ibid.
} 


\section{CORPORATE LAWS AMENDMENT ACT 24 OF 2006}

Section 38 was further amended by section 9 of the Corporate Laws Amendment Act by insertion of subsections $2(A)$ and $(B)$. The Corporate Laws Amendment Act permits a company to provide financial assistance for the purpose of purchase or subscription of shares provided that the approval by special resolution is made and the transaction will pass the liquidity and solvency test. ${ }^{42}$

\section{SECTION 44 OF THE COMPANIES ACT 71 OF 2008}

Section 44 regulates the situation where a company provides financial assistance for the acquisition of the company's securities. ${ }^{43}$ Section $44(2)$ provides that:

"Except to the extent that the MOI provides otherwise, the board may authorise the company to provide financial assistance by way of loan, guarantee, the provision of security or otherwise to any person for the purpose of, or in connection, the subscription any option, or any securities, issued or to be issued by the company or a related or inter-related company, or for the purchase of any securities of the company or a related or inter-related company, subject to subsections (3) and (4)".

Delport states that it is not clear how the Board can authorize the company (represented by the Board) to provide financial assistance ${ }^{44} \mathrm{He}$ is of the opinion that the correct construction should be that the company authorizes the Board (as agents of the company) because the contracting party, with rights and obligations, remains the company. ${ }^{45}$ He further refers to section 66 which appears to change the ultimate organ in the company. ${ }^{46}$ According to him, financial assistance is the norm, unless the MOI excludes or limits it and if $\mathrm{MOI}$ is silent, the company/Board has the power to provide financial assistance. He concludes by stating that the authorization must obviously be by the Board's resolution.

Section 44(3) provides that despite any provision of the Company's MOI to the contrary, the Board may not authorize any financial assistance in section 44(2) above, unless the particular provision of financial assistance is:

“(a)(i) Pursuant to an employee-share scheme that satisfies the requirements of section 97 ; or

42 See s 38(2A) of the Act 61 of 1973; and s 9 of the Corporate Laws Amendment Act 24 of 2006.

43 S 1 of the Companies Act 71 of 2008 stipulates that securities has the meaning "set out" in $\mathrm{s} 1$ of the Securities Services Act 36 of 2004 and includes shares held in private company. S 1 of the Securities Services Act 36 of 2004 define securities as any shares, debentures or other instruments, irrespective of their form or title, issued or authorized to be issued by a profit company. Delport indicates that this is much wider definition than was previously the case. He also indicates that securities include shares but shares do not include securities, Delport The New Companies Act Manual 29 (fn 1).

44 Delport The New Companies Act Manual 54 (fn 6).

45 Ibid.

46 Ibid.

47 lbid. 
(ii) pursuant to a special resolution of the shareholders, adopted within the previous two years, which approved such assistance either for a specific recipient, or generally for a category of potential recipients, and the specific recipient falls within that category; and

(b) the Board is satisfied that -

(i) immediately after providing the financial assistance, the company would satisfy the solvency and liquidity test; and

(ii) the terms under which the financial assistance is proposed to be given are fair and reasonable to the company.

Section 44(4) imposes the duty on the Board to ensure that any conditions or restrictions respecting the granting of financial assistance set out in the company's MOI have been satisfied. Section 44(5) provides that a decision by the Board to give financial assistance will be void if such a decision is inconsistent with section 44 or is inconsistent with a prohibition, condition or requirement of section 44(4). In terms of section 44(6), a director who was present and did not vote against the resolution, can be held liable for any loss, damage or costs sustained by the company if the resolution has been declared void under section 218. Delport states that, although the resolution or the agreement in contravention of section 44 or the provision in the $\mathrm{MOI}$ is void (section 44(5)), it must still be declared void by the court in terms of section 218(1) or 77(5)(a) and that is only when non-compliance will result in the director's civil liability under section $77(3)(\mathrm{e})(\mathrm{iv}){ }^{49}$ He further indicates that the general liability provision (section $77(3)(e)(i v)$ ) does not require this. $^{50}$

\section{The meaning of financial assistance}

Section 44(1) provides that "financial assistance" does not include lending of money in the ordinary course of business by a company. Section 44(2) states that financial assistance includes loan, guarantee, the provision of security or otherwise. Like section 44, section 38 of the old Act also covers financial assistance "by means of loan, guarantee, the provision of security or otherwise". ${ }^{51}$ The Act does not define the term "financial assistance". The court, in Anglo Petroleum Ltd $v$ TFB (Mortgages) $L t d{ }^{52}$ indicated that it is unwise for the legislature to lay down a precise definition of the term and this could give rise to uncertainties and ambiguities. ${ }^{53}$ Delport states that since the Act does not define the term "financial assistance", the common-law definition in terms of the Act 61 of 1973 Act will be used to determine whether there was a financial assistance ${ }^{54}$ In Gradwell $v$ Rostra Printers $L t d^{55}$ the court formulated test called "impoverishment" and this has been

48 See Delport and Vorster Henochsberg on the Companies Act 71 of 2008 (2011) 190 in which they state that there is no indication what fair and reasonable in this context would be. They submit that the provisions of s 37(3)(c) of the Act 61 of 1973 could be indicative.

51 Cassim, Cassim, Cassim, Jooste, Shev and Yeats Contemporary Company Law 2ed (2012) 316.

52 [2008] 1 BCLC 185 (CA) 26 190-191.

53 Ibid; and see Cassim et al Contemporary Company Law 316.

54 Delport The New Companies Act Manual 55.

551959 (4) SA 419 (A). 
always used by the court to determine whether financial assistance was given. The test involves the question whether the company had become poorer in consequence of what it did for the purpose of or in connection with the purchase or subscription of shares $;^{56}$ in other words, whether it entails financial assistance before and after the transaction is evaluated. ${ }^{57}$ It therefore follows that, if a company is in a worse financial situation by the transaction, it is impoverished. ${ }^{58}$ Delport states that this will happen for example, if the company registers a bond over its property to secure a bank loan made by the buyer of the shares ${ }^{59}$ or if the company creates a fictitious debt (not based on bona fide transaction) in favour of the seller. ${ }^{60}$

\section{2 "For the purpose of", or "in connection with"}

The court, in Lipschitz v UDC Bank, held that the prohibition in section 38 comprised two main elements, one was the giving of financial assistance, and the other was the purpose for which it was given (or the "in connection with" provision). The court further indicated that the words "in connection" was an alternative to "for the purpose of", and in the context of the section its connotation was greatly affected by the concept to which it was an alternative. ${ }^{61}$ In Brandy $v$ Brandy, ${ }^{62}$ the House of Lords drew a distinction between the "purpose" and the "motive" or "reason" why a purpose is formed. The House of Lords said:

"The purpose and the only purpose of the financial assistance is and remains that of enabling the shares to be acquired and the financial or commercial advantages flowing from the acquisition, are a by-product of it rather than independent purpose of which the assistance can properly be considered to be an incident".

The court in Lipschitz $v$ UDC Bank, indicated that, where the purpose of the company in performing the act complained of was established, and that purpose was for something other than the purchase of the company's shares, there would be a little or no room for finding that for purpose of section 38 the Act was nevertheless performed in connection with the purchase of shares. ${ }^{64}$ The court gave the following example:

56 See Cilliers et al Cilliers and Benade Corporate Law 331. In Sterileair (Pty) Ltd v Papallo (1998) 29 ACSR 461466 the court indicated that assistance involved something in nature of aid or help. The court went on to state that assistance could not exist in vacuum, it had to be therefore given to someone. The assistance had to be financial Armour Hick Northern Ltd v Armour Trust Ltd supra 837-838; London Ranch (Pty) Ltd v Hyreb estate (Pty) Ltd 1963 (2) SA 570 (E).

57 Delport The New Companies Act Manual 55.

58 Ibid. See fn 16 above for the decision of Lewis $v$ Oneanate (Pty) supra 816-817 for the propositions that were extracted by the court from Lipschitz NO $\vee$ UDC Bank Ltd with regard to financial assistance.

59 Karroo Auctions v Hersman 1951 (2) SA 33 (E).

60 Albert v Papenfus 1964 (2) SA 713 (E); and Delport The New Companies Act Manual 55.

61 Lipschitz v UDC Bank supra 805; and see Cilliers et al Cilliers and Benade Corporate Law 333.

62 [1988] 2 All ER 617 (HL) 633.

63 lbid.

64 Lipschitz v UDC Bank supra 805. 
“Company A, for its own business purposes, guarantees B's overdraft at a bank so as to enable $B$ to carry on his business as manufacturing certain equipment which the company necessarily requires for its business and which equipment it purchases from B. Company A knows full well at the time of giving guarantee that $\mathrm{B}$, who has confidence in its stability and management, intends to invest in shares in the company $A$ the surplus profits he will make as a result of being able to continue is manufacturing business by reason of the overdraft facilities made available to him by virtue of A's guarantee. B in fact thereafter uses such profits for the purchase of shares in $A$. The guarantee given by A clearly amounts to the giving of financial assistance to $\mathrm{B}$, but not at all for the purpose of the purchase of the company's shares; its purpose, clearly established, was to enable B to continue producing the equipment required by $A$ for its business. In such a case there would surely be no room for finding that, because A knew of B's ultimate intention regarding the purchase of shares in the company, the financial assistance given by $A$, although not given for the purpose of purchase but for a different purpose, was nevertheless given in connection with the purchase of shares and was therefore in contravention of the section".

In sum, the words "for the purpose of", or "in connection with" appears in section 44 and therefore the decision of Lipschitz $v$ UDC Bank will apply to the new Act.

\section{The requirements to provide financial assistance in terms of section 44}

In terms of section 44(3), the following requirements must be complied with before the company provides financial assistance.

\section{Memorandum of Incorporation (MOI)}

The MOI must permit the company to provide financial assistance. It must state clearly that the company can give financial assistance.

\section{Employee-share scheme or special resolution}

Section 44(3) provides that the Board may not authorize any financial assistance unless the particular provision of the financial assistance is pursuant either to an employee-share scheme that satisfies the requirements of section 97 , or to a special resolution of the shareholders adopted within the previous two years.

\section{Solvency and liquidity test}

Section 44(3)(b) stipulates that the Board may authorize the company to provide financial assistance, if the Board is satisfied that immediately after providing financial assistance, the company would satisfy the solvency and liquidity test. Delport argues how the Board can authorize the company. $\mathrm{He}$ indicates that the company should authorize the Board. ${ }^{66} \mathrm{He}$ put it as follows:

65 Ibid.

66 Delport The New Companies Act Manual 54 (fn 6). 
"It is not clear how the Board can authorise the company (represented by the Board) to provide financial assistance. The correct construction should be that the company authorises the Board (as agents of the company) because the contracting party, with the rights and obligations, remains the company".

Delport further refers to section 66 and indicates that it appears to change the ultimate organ in the company. ${ }^{68} \mathrm{He}$ is of the opinion that financial assistance is now the norm, unless the $\mathrm{MOI}$ excludes or limits it. $\mathrm{He}$ indicates that, if the $\mathrm{MOI}$ is silent, the company or Board has the power to provide financial assistance. Finally, he expresses his view that the authorization must obviously be by the Board resolution. ${ }^{69}$

As indicated earlier, section 4(1) stipulates that the company satisfies a solvency and liquidity test at a particular time, when considering all reasonably foreseeable financial circumstances of the company at that time, the assets of the company as fairly valued equal or exceed the liability of the company and it appears that the company will be able to pay its debts as they become due in the ordinary course of business for the period of 12 months from the date on which the test is considered, or in the case of distribution, 12 months following that distribution. Therefore, the financial assistance to be considered by the company must be based on accounting records that satisfy the requirements of section 28 , and financial statements that satisfy the requirements of section $29 .^{70}$ Van der Linde states that the test imposes an objective test rather than a subjective test. ${ }^{71}$ She indicates that the determining factor is the existence of reason or ground upon which a conclusion could reasonably be reached. She further indicates that a resolution by the board that it has "reasonably concluded" that the company will satisfy the test is set as an additional requirement in certain instances. ${ }^{72}$ Delport is of the opinion that the outcome of the test, in respect of solvency, is objective as well as subjective in that it appears that it will remain liquid for the following 12 months.

\section{Exception to section 44}

Section 44(1) provides for the exception to the application of section 44. In particular, section 44(1) stipulates that "financial assistance" does not

67 Ibid.

68 S 66 stipulates that the business and affairs of a company must be managed by or under the direction of its Board, which has the authority to exercise all of the powers and perform any of the functions of the company, except to the extent that this Act or the company's MOI provides otherwise. See Delport and Vorster Henochsberg on the Companies Act 71 of 2008189 , where Delport and Vorster argue that the concept Board as organ or agent of the company can "authorize the company" is foreign to the common law but is now possible under s 66(1).

69 Delport The New Companies Act Manual 54 (fn 6).

$70 \mathrm{~S} 4(2)$.

71 Van der Linde "The Solvency and Liquidity Approach in the Companies Act 2008" 20092 TSAR 224235.

72 Ibid.

73 Delport The New Companies Act Manual 54. See Delport and Vorster Henochsberg on the Companies Act 71 of 2008 191, in which they further indicate that the words "Board is satisfied" is a subjective test, but qualified by the objective "reasonably foreseeable circumstances" in s 4. 
include lending money in the ordinary course of business by a company whose primary business is the lending of money. Therefore, a person who wishes to purchase or subscribe shares in a company whose primary business is the lending of money will have to approach such company for a loan.

\section{Liability and validity of contracts}

Section 44(5) provides for the consequences for non-compliance with section 44(2). It stipulates that a decision by the Board of a company to provide financial assistance, or an agreement with respect to the provision of any such assistance, is void if it is inconsistent with the section 44 or a prohibition, condition or requirement in the MOI. Section 44(6) provides that, if a resolution or agreement is void in terms of section 44(5), a director of a company will be liable in terms of section $77(3)(e)(v)$ if he was present at that meeting when the Board approved the resolution or agreement or participated in the making of such decision in terms of section 74 , and failed to vote against such resolution or agreement despite knowing that the provision of financial assistance was inconsistent with section 44 or a prohibition, condition or requirement of section 44(4). The directors who were present at the meeting and did not vote against the resolution can be held liable only for loss, damage or costs sustained by the company. ${ }^{74}$

\section{COMPARISON OF SECTION 38 OF THE OLD ACT AND SECTION 44 OF THE NEW ACT}

Section 38 contains a strict prohibition on the company to provide financial assistance. This is confirmed by the words "no company shall give". In terms of section 38 a company is not allowed to provide financial assistance. Section 44 permits a company to provide financial assistance. This is confirmed by the words "a company may", whereas it was not possible in terms of section $38 .{ }^{75}$

Section 38 further provides that "you will be guilty" of an offence if you do not comply with it, whereas section 44 does not indicate anything like an offence that you will be guilty of. Section 44 stipulates only that the directors will be liable as in section 38 .

Section 38 will not apply if financial assistance is given by holding company to buy shares in the subsidiary or "related company". Section 44 provides for financial assistance for the purpose of buying shares, not only in the holding company, but also in a subsidiary (or related company). A holding company that provides financial assistance to subsidiary must comply with section 44 .

74 Delport The New Companies Act Manual 56; and s 77(3)(e)(iv).

75 Ibid. 


\section{CONCLUSION}

Section 38 which prohibits a company to give financial assistance for the acquisition of shares in the company or in its holding company was amended by 90 of the Companies Amendment Act 37 of 1999. Surprisingly the legislature failed to remove the prohibition in 1999 and only incorporated the solvency and liquidity test. As indicated earlier the repealed section 38 also prohibited a subsidiary to provide financial assistance to any person for the purchase or subscription of shares in its holding company. The exception in section 38(2)(d) was subject to many interpretations and it is suggested that it is unclear, ${ }^{76}$ containing curious exceptions ${ }^{77}$ and, because of these uncertainties, is virtually useless. ${ }^{78}$ Interestingly section 44 of the new Act permits a company to provide financial assistance for the acquisition of or subscription of company's securities. It further provides for financial assistance for the purpose of buying shares, not only in the holding company, but also in a subsidiary (or related company). The new Act is wholly based on the solvency and liquidity test. In order for the company to provide financial assistance the following requirements in section 44 should be complied with:

- The MOI must permit the company to provide such financial assistance;

- the Board may not authorize any financial assistance unless the particular provision of the financial assistance is pursuant either to an employeeshare scheme that satisfies the requirements of section 97 or to a special resolution of the shareholders adopted within the previous two years;

- the Board must be satisfied that, immediately after providing financial assistance, the company would satisfy the solvency and liquidity test.

\footnotetext{
Blackman et al Commentary on the Companies Act 4-66.

Cilliers et al Cilliers and Benade Corporate Law 330 (fn 52).

78 Delport 200113 SA Merc LJ 125-126.
} 